\title{
Deconstructin(g) Jazz Improvisation: Derrida and the Law of the Singular Event $^{1}$
}

\section{Sara Ramshaw, Queen's University Belfast}

\author{
"It was the music. [...] It made you do unwise disorderly things. Just hearing it was like \\ violating the law."
}

"[E]very invention should make fun of the statutory."

Toni Morrison (Jazz 58)

Jacques Derrida ("Psyche" 45)

Paris, July 1997. Famed jazz saxophonist Ornette Coleman has just invited French philosopher Jacques Derrida to share the stage with him at the Paris La Villette jazz festival for an improvised jazz-text collaboration (Nettelbeck 198). Coleman "blows" while Derrida "read[s]" ${ }^{2}$ (Stein). The audience members, "intolerant of this unaccustomed form," (Nettelbeck 198) drive Derrida off the stage before he can "get into his stride" (198). ${ }^{3}$ His contribution to the event is "pathetically foreshortened" (198) and Derrida is left shaken by the "painful experience" (qtd. in Stein). ${ }^{4}$

Of particular interest to this article is the willingness of Derrida to collaborate with Coleman in this manner especially when his arguments against the possibility of "spontaneity, improvisation and unmediated expression" (Gartside, qtd. in O'Reilly) are often cited in order to critique jazz and jazz improvisation (O'Reilly). Coleman, in contrast, attempts everything Derrida says is impossible in relation to improvisation: "Breaking out of the prison bars of rigid meters and conventional harmonic or structural expectations" (Goldman); resisting "hierarchical distinctions between improvisation and inscription" (Nettelbeck 200). His "harmolodic" (Goldman) musical form taunts the laws governing the system of Western tonal music, "encourag[ing] the improviser to be freer, and not obey a pre-conceived chord-pattern according to set ideas of 'proper' harmony and tonality" (Williams 3). Throughout his performances, "harmony becomes melody becomes harmony" (Goldman) and the division between the melodic and harmonic forms ${ }^{6}$ is effectively ignored, transgressed. ${ }^{7}$ As Coleman is quoted as saying in the liner notes of his Free Jazz album: "Let's try to play the music and not the background" (qtd. in Williams 3). By "background," Coleman is referring to the "general framework of jazz improvisation which had established itself soon after the birth of jazz as a more or less incontestable norm" (Jost 17). This "framework," Jost claims, "consisted of a code of agreements which made up [...] the 'musically universal' in jazz, and remained constant throughout the years of jazz evolution, while the 'musically particular' changed" (17).

Driving this discussion is a deep scepticism, fuelled by Derrida, as to whether jazz improvisation can actually transgress or ignore the "background" of which Coleman speaks. Can it, borrowing from Haldar, "properly" (Haldar 7) escape jazz's law, the law of jazz, which "hums in the background" (Haldar 1)? Or, far from "bring[ing] down the law" (5), is improvisation "nothing more than the law of law" (5), "nothing more than the repetition of man's vertical aspirations?" (5). ${ }^{8}$

Before attempting to answer these questions, I must briefly address a preliminary matter about which many readers may be curious, namely what is this "law of jazz" mentioned above? Or, more pointedly, what is "law"? Although the aim of this article is to locate it not as unity, but as "irresolution" (Fitzpatrick Mythology 2), law persists in the West as a unified subject, a subject that is "'out there', perfectly formed, complete and coherent, waiting to be discovered" (Douzinas et al x). It persists, at least in its generic sense, as "a body of rules of action or conduct prescribed by controlling authority, and having legal binding force" (Black 884). The ideal of the rule of law in Western democratic society means that "everyone is bound by the law" (Pue 17, emphasis omitted): "the very nature of law is that it applies to us all" ("Head-to-head"). Moreover, it is "presume[d] that before citizens' liberties and freedoms are restricted, the full protection of constitutional rights and the political protections provided by our parliamentary system of government will be brought into play" (Pue 17, emphasis omitted). Determinations of what is and what is not lawful remain under the control of the democratically-elected legislature; police are employed to enforce these laws and courts adjudicate any alleged infractions or disputes over meaning (17).

In keeping with this dominant view, Western law must eschew all spontaneous or unpredictable elements. This can be starkly contrasted to the prevailing perception of jazz in the West as that which is founded solely upon pure spontaneous improvisation. Both conceptions are, when deconstructed, ultimately found wanting. This article therefore aims to critique the positioning of Western law and jazz in relation to improvisation by 
reading Derrida's work on law and justice ${ }^{9}$ in tandem with his views on invention ${ }^{10}$ and then applying the consequent observations to the topic of jazz improvisation. While improvisation ${ }^{11}$ and invention ${ }^{12}$ are by no means identical, they do share certain qualities that become extremely relevant when explored through a deconstructive framework. ${ }^{13}$ Both concepts describe "event[s] without precedent" (Derrida "Psyche" 43), "unique situation[s]" (60), which are constituted in their "singularity" (28). This singularity, albeit contested, can be starkly contrasted to the dominant conception of Western law, which privileges generality and universality over unpredictability and arbitrariness.

In his writings on law and invention, Derrida unpacks the "problematic relation between the singular and the general" (Attridge "Before the Law" 181) in order to challenge the pure presence of singularity in invention, along with the universality, which is said to propel occidental law. His observations, when applied to the critical study of jazz improvisation, confront the prevailing understanding of improvisation as sheer spontaneity and thereby challenge its exaltation in jazz and concurrent condemnation in law. A deconstructive reading reveals that improvisation so defined can be neither total in jazz nor totally absent in law. Instead, the singular event exists solely as aporia in both fields. This unpacking of the aporetic nature of singularity reveals not only the inevitability of legal invention, but also the necessity of the "jazz form" 14 (Finkelstein 71). Beyond this, however, and perhaps shedding some light on Derrida's participation in the "improvised" event described above, there exists an openly responsive dimension to both jazz and law. This dimension, although never complete or absolute, glances towards the singular other ${ }^{15}$ and keeps alive the possibility of creativity, ethics, democracy and justice in Western law and society.

\section{Irresolution in Jazz and Law}

When asked "What is jazz?" Louis Armstrong purportedly replied, "Man, if you have to ask, you'll never know" (qtd. in Hyman 3). ${ }^{16}$ This celebrated response has become authority for the position that there is "no single workable definition of jazz, no single list of essential characteristics" (DeVeaux 6, emphasis in original; see also Townsend 162). Imagined here is a jazz that is "know"-able only to the extent that it has no definite or determinate meaning. It is music defined solely by its un-define-ability, by its inability to be tied down, contained or fixed in content. This understanding of jazz is undoubtedly linked to its supposed "deliberately improvisatory form" (Levinson and Balkin 1623; see also Hall 1599; Finkelstein 71; Hentoff "Jazz" 95): "Improvisation is always changing and adjusting, never fixed, too elusive for analysis and precise description" (Bailey ix). Any attempt to define or describe jazz improvisation is thus said to constitute "a misrepresentation, for there is something central to the spirit of voluntary improvisation which is opposed to the aims and contradicts the idea of documentation" (ix; see also Nachmanovitch 12). ${ }^{17}$

To equate jazz so fully and inevitably with improvisation is not without its problems. Not the least of which is the impoverished view, dominating the West, regarding the techniques of improvisation. To the uninitiated, improvising jazz musicians "seem to be making all of it up as they go along" (Gabbard 315; see also Stewart 96; Demsey 788). This perception is not only decidedly incorrect it has "racist" (Derrida "Play" 332) undertones. Improvisation, in accordance with this understanding, is envisaged as "primitive" (Gilroy 294; Gabbard 300), "instinctive" (Townsend 8), "unconscious" (Finkelstein 17; Gabbard 301); "compensation for a deficiency (the inability to read written music), or [...] a freakish kind of gift (the jazz musician as the spontaneous, innocent, 'natural' player)" (Townsend 8). Despite the enormous "skill and devotion, preparation, training and commitment" (Bailey xii), which go into jazz improvisation, listeners continue to regard the improviser as an "ego-driven mystic who is unable to describe his or her own creative process" (Lewis "Afterward" 170).

While attentive to this dilemma, it is also the case that certain types of jazz have, in the past, focused largely on improvisation, thereby contributing to this vision of jazz as "largely improvisational in nature" (Hall 1599). Take bebop for example. Developed between 1939 and 1941 in after-hours jam sessions at Monroe's Uptown House and Minton's Playhouse in Harlem, bop adopted the improvisational focus of the jam session - "where the paramount concern was unbroken momentum" (DeVeaux 377) - and in so doing "radically revised the prevailing definition of jazz" (202; see also Jones 64). Musicians who gathered in these Harlem venues after an evening of playing in a large orchestral swing band would concentrate on "learn[ing] new techniques" (Belgrad 180) and practicing solo improvisation, a musical process that had little place in swing performances (180). This attentiveness to spontaneous invention greatly contributed to bebop's standing as "an aggressive, esoteric music, difficult to understand or to play, and deliberately so" (Chevigny 45). Bop was labelled "mad, wild, frantic, crazy" (Hughes 118) and was lauded as "revolutionary" (Chevigny 45; Ross 257; Ellison 201; Green 39): a "music of revolt, revolt against big bands, arrangers, vertical harmonies, 
soggy rhythms, non-playing orchestra leaders and Tin Pan Alley; against commercialized music in general" (Allsop 33).

Many other factors contributed to bebop's "wild" and "revolutionary" reputation. Perhaps the most significant was the "black character of the revolution" (DeVeaux 18): "black musicians [such as Charlie Parker, Dizzy Gillespie, Thelonious Monk and Bud Powell, to name a few] dominated bop in a way that they had not dominated other forms of jazz since the early days" (Collier 209). Many argue that bop was developed in order to prevent the parasitic appropriation and exploitation of jazz by white musicians, musicians who had, in the past, "stole" swing (and ragtime) and who were then offered all the best recording contracts and live performances (Allsop 33; Green 39; Hentoff "Race Prejudice" 73; Ellison 212; Hore). It has also been suggested that bop began as "a militant demonstration against 'Uncle Tomism"' ${ }^{18}$ (Allsop 33; see also Beyer 542) and was a "political" attempt to turn jazz into an art music (Green 39), to make it "a music meant for listening and not for dancing" (Belgrad 187).

No matter what the reason for bop's emergence, in their refusal to cultivate a stage persona or to entertain (white) audiences, bebop musicians were met with much racial antagonism. As one observer remarked, having seen the Parker-Gillespie quintet perform:

That [bebop] sounded arrogant, uppity. [...] [When I] saw Bird's combo, what struck me even more than the music was the attitude coming off the bandstand - self-confident, aggressive. It was something l'd never seen from black musicians before. (qtd. in DeVeaux 435, emphasis in original)

Bebop was accordingly positioned in violation of not only the laws of melodious musicality, but also the rule of law in Western society. It was constituted either as "arrant foolishness, a farrago of nonsense syllables and noisy, incomprehensible music" (440) or as "an underground of drug users, antisocial deviants, and racial militants" (440; see also Allsop 34). "Both impressions," notes DeVeaux, "were informed by racially grounded stereotypes" (440).

Another influential factor in the construction of bebop as "wild" and transgressive was its connection to the after-hours jam session, that seemingly lawless space, which brought bebop into being and gave it its improvisational focus. As a product of the jam session, bop was considered as "structure-less or chaotic" (Alterhaug 103) as the sessions themselves. The dominant perception of the jam session as eschewing all law is influenced to a large degree by the fact that it offers "few clues to the uncontexted outsider" (DeVeaux 203) regarding its nature and structure. No written music is evident and there is "certainly no rehearsal" (203). No stable or definitive "house band" exists and musicians "come and go as they please, even during the middle of the number" (203). The performances are without "frame" (203) and there are "no spoken introductions or attention-getting silences" (203): "Hardly a word is exchanged beyond a few cryptic phrases - 'blues in B-flat,' 'rhythm changes,' a quick countdown to set the tempo - and they are off, into a performance that may last anywhere from a few minutes to an hour" (203). All the musicians in the jam session seem to "know what to do without being told" (203) and "[t]he listener is left face to face with the mystery of improvisation - an alchemy that creates music out of nothingness" (203, emphasis added).

It is the "mystery of improvisation" (203), which best lends itself to the transgressive positioning of jazz within Western society. As unique and "unforeseen"19 (Lewis "Improvised" 145), jazz improvisation is meant to eschew all law, convention, structure or form. It is constituted as "pure spontaneity" (148) to the exclusion of "history or memory" (147; see also Panish 120). Many musicologists and musicians criticize this understanding of improvisation. Wynton Marsalis, for instance, is quoted as saying: "Jazz is not just, "Well, man, this is what I feel like playing.' It's a very structured thing that comes down from a tradition and requires a lot of thought and study" (qtd. in Berliner 63). ${ }^{20}$ Improvisation is thus not simply "a process of creation that emphasizes freedom and spontaneity" (Panish 123). To improvise well requires an attention to "discipline" (Lewis "Improvised" 153), "technical knowledge" (153), as well as "background, history, and culture" (153).

A tension consequently exists between the "spontaneous" conception of jazz improvisation and the more context-driven model. This tension is intrinsic to jazz improvisation itself. Improvisation can be neither purely spontaneous nor completely determined by the musical structures with which it engages. It must be both responsive to otherness and have some stable or determined dimension in order to endure as jazz improvisation. Thus, quoting saxophonist Steve Lacy, improvisation sits "on the edge - in between the known and the unknown and you have to keep pushing it towards the unknown otherwise it and you die" (Bailey 54). 
Western democratic law holds similar contradictions. The dominant, or what George Lewis calls the "Eurological" 21 (Lewis "Improvised" 133), view of improvisation positions it as utterly spontaneous in opposition to a stable and determinate set of laws and practices governing Western music. The same dichotomy underlies the conception of Western law. Following Hobbes (1651), Rousseau (1762) and, somewhat later, Freud (1913), the tale of law's founding is almost always told in relation to a violent uncertainty or "state of nature" from which "we" allegedly escaped (Manderson "From Hunger to Love" 88). Unpredictability is thence constituted as something external to Western law, as that which must be reined in or controlled. Far from being improvised or unforeseen, law is said to furnish "us moderns" (Fitzpatrick "Access" 8) with "a haven of certainty in an uncertain world" (8). Asserted again and again is the idea that law "provided and provides an imperative certainty and predictability" (8), especially in relation to "transitions to modernity, and in the sustaining of modern economic relations in particular" (8). What is more, it is these "pre-announced rules that are clear and intelligible in themselves" (MacCormick 12), which "we most often expect from the law" (Deutscher 97).

The rule of law in Western society thereby demands that any inventive or unpredictable qualities be strictly managed or denied. As the argument goes, if law could simply be invented in "each act of decision" (Fitzpatrick Modernism 87), it would hold "no set and enduring truth" (87). Any invention of law by judges or others must be determinately contained or restricted through, inter alia, the device of legal precedent or stare decisis. ${ }^{22}$ Precedent, in its reliance on past legal decisions, assures that "like cases will be treated alike, and that similarly situated individuals are subject to the same legal consequences" (Rehnquist 347). As a guard against the "arbitrary and capricious" (Nitta 798), precedent "provides certainty in the law" (797) and "allows citizens to arrange and conduct their affairs with stability and predictability" (798).

This seemingly straightforward account of precedent nonetheless belies the rather complex relationship of law to invention. For every lawyer or legal theorist who condemns judge-made law or judicial activism (Bork), there are others, such as legal realists (Frank) or critical legal theorists (see, for example, Bucholtz; Margulies; and Silbey and Ewick), who applaud any inventive techniques in law. This lack of consensus as to the role invention plays actually flows from the very nature of the legal decision. Every judicial act is, in "a trivial sense" (Dworkin 6), a species of invention. As no two actions can be exactly the same, judges "make new law" (qtd. 6) every time they are asked to decide a case. Law can thus neither dispense with, nor be completely determined by, the device of precedent (Deutscher 98). The legal decision instead lies on the "horizon" (Fitzpatrick "Breaking the Unity" 58), the border between "what it is" (Fitzpatrick Modernism 89) and what it otherwise could be (89). While bebop jazz, for example, must mask its structured elements ${ }^{23}$ in order to continue as a revolutionary and creative art form, the inverse is true for law: the inventive dimension of law must be subordinated to tradition and precedent in order to endure as authoritative and commanding in Western society. The "most popular opinion" (Dworkin 8) thereby remains that judges should simply find or discover the law that "already is" (6) and those who invent or "make new law" (qtd. 6) are viewed to be "bad judges, the usurpers, destroyers of democracy" (8; see also Cohen 25).

\section{Derrida and Music}

The conceptualisation offered above envisages an improvisation that is venerated in jazz, an invention degraded in law, but neither being able to subsist solely "as such" in either field. An irresolution thus exists as to the role of improvisation and invention in law and jazz, one that is simply confirmed by the dissident voices rising up from both disciplines. In order to fully understand this irresolution, Derrida's work on law and invention becomes most instructive. As a prerequisite to this discussion, though, I must engage briefly with the question of whether Derrida's thoughts can in fact be applied to the musical genre of jazz. The philosopher himself is of little assistance here for, despite being an avid jazz fan (O'Reilly; Stein), nowhere in his discussions on invention does Derrida mention jazz or jazz improvisation (or any form of musical invention to be exact). ${ }^{24}$ This omission does not necessarily negate the possibility of deconstructing music. In fact, Derrida himself reportedly endorsed the attempt, remarking to Rose Subotnik that he "would be interested to see what resulted" (Subotnik 39) from her deconstruction of a Chopin prelude (39-147). Notwithstanding this endorsement, however, a brief exploration into whether one can apply a deconstructive framework to the topic of jazz improvisation needs to be undertaken.

For this inquiry, we return to Paris. This time the exact date is unknown. ${ }^{25}$ Pop star, Green Gartside, lead singer and composer for the pop band, Scritti Politti, has just been invited to meet with the philosopher after writing a song entitled "Jacques Derrida" (Rough Trade Records 1982), which Derrida's students played for 
him (O'Reilly). When Gartside was asked years later what he and Derrida spoke about at that meeting, he answered with the following:

Oh, music! [...] As I remember, he likes jazz, which was pretty neat 'cause I had it in me to ask him some things. Half-jokingly, I said, "Well, isn't it true that jazz is valued for its spontaneity and improvisation, the idea that it represents the moment of self-present expression and meaning? But isn't that all somewhat suspect?" (qtd. in Chang)

Derrida's reply to this query remains undocumented. However, Gartside plays an important role in this discussion for, despite being well-versed in deconstructive theory, he remains convinced that there is something unique to music, which positions it "outside the limits of language and logocentrism" (qtd. in Hoskyns). Its "meaning or its sense," in other words, is not "determined by language" and cannot be found "innately residing within four beats to the bar" (qtd. in Hoskyns).

Gartside is nevertheless not blind to the metaphysical limits of music: "no one musical phenomenon is ever going to transcend beat or repetition, nor is it ever going to transcend the history of criticism and the industry" (qtd. in Hoskyns). Despite this admission, however, he does believe that "[i]t is possible, but again only in a metaphysical way, to think and talk about music as something that undoes" (qtd. in Toop, emphasis in original). Quoting Gartside:

When I met Derrida he said that what I was doing was part of the same project of undoing and unsettling that he's engaged in. He's written that what sets the musician apart is the possibility of meaninglessness. That unsettling has always been my experience of pop, from the earliest moments - pop is the abuse of language. (qtd. in Reynolds)

Musicologist Marcel Cobussen disagrees with Gartside's assertion that music is meaningless: "Of course (pop) music has meaning; it has political, economic, social, cultural and psychological meaning (and I am not only referring to its lyrics here). In this sense, we can approach music through language, through all kinds of discourses on music" (Cobussen "Scritti Politti" para. 5). However, he admits that Gartside "points to something, a non-localizable place, where music transgresses the power of language" (para. 5). Cobussen writes:

We cannot understand music the same way we understand language. Music is a language, music is text, but it is not the same as a spoken or written language. Because something in music always escapes comprehension, understanding. Language fails to make music completely transparent. Music appeals to something that exceeds the semantic part of language; it appeals to non-discursive sonority. (Para. 5)

Unfortunately, we are unable to look to Derrida for answers to this dilemma. As noted above, he never really engaged with the topic of music in his work. ${ }^{26}$ When asked by Gartside why he never wrote a book expressly on the subject, Derrida replied that to do so was "the most difficult thing" (qtd. in O'Reilly). Instead, his "loftiest aim" was to give his texts "the condition of musicality" (qtd. in O'Reilly; see also Roberts). In one interview he is quoted as saying: "music is the object of my strongest desire, and yet at the same time it remains completely forbidden. I don't have the competence. [...] I am even more afraid of speaking nonsense in this area than in any other" (Brunette and Wills 21).

Derrida's refusal to write on the topic of music cannot be relied upon as evidence of its inability to signify. However, his silence on the subject has led some theorists to argue that he simply "stays closely connected to the philosophers he criticizes" (Cobussen "Derrida's Ear" para. 4) and that "[h]is deconstructive practices do not reach the sonorous domain, the domain of music" (para. 4). Musicologists such as Cobussen, however, defend the deconstruct-ability of music and argue that Derrida touches on the idea of sonority in his treatment of "words," which he likens to "non-discursive sonority" (Cobussen "Justification" para. 6). As Derrida asserts in an interview with Brunette and Wills:

And if I love words it is also because of their ability to escape their proper form, whether they interest me as visible things, letters representing the spatial visibility of the word, or as something musical or audible. That is to say, I am also interested in words, paradoxically, to the extent that they are nondiscursive, for that's how they can be used to explode discourse. (Brunette and Wills 20) 
Although Derrida does not go so far as to call this non-discursive sonority music(al), according to Cobussen, his treatment of "words" in this manner "opens a way to connect Derrida's thoughts to music" (Cobussen "Justification" para. 6).

This is a debate to which I, a lawyer, have nothing personally to add. ${ }^{27}$ Instead, I defer to Cobussen and insist on the possibility of a Derridean critique of jazz improvisation. My deference may irritate some musicologists. Ingrid Monson, for instance, has held that deconstruction "may make sense in the context of debates in Western philosophy" (Monson 209), but "it has done considerable damage to understanding the ways in which music as a sonic phenomenon and human agency participate in the construction of social and cultural meaning" (209). While ever mindful of the limitations of deconstructive theory, especially in relation to the Western metaphysical tradition within which it operates, I find myself unconvinced by her argument. Deconstruction is found wanting by Monson in that it "values writing over speech and grounds the decentering of the subject" (209). What her interpretation ignores, however, is that, for Derrida, no concept can ever be so fully secured with determinate meaning such that it could become so privileged. Moreover, while Derrida may have "no interest in defining subjectivity" (Morgan), he does not "want merely to get rid of the subject in a nihilistic fashion" (Morgan). Thus, not having been persuaded to the contrary, I align myself with those who regard the application of Derrida's thought to music as a viable and promising endeavour (see, for example, Subotnik) and I proceed to critique, deconstructively, the established conception of improvisation as "the essence of" (Collier 25) jazz and the nemesis of law. ${ }^{28}$

\title{
The "Mystical Foundation" of Jazz Improvisation ${ }^{29}$
}

\author{
"When you're just learning jazz, everything is mystical." \\ Wynton Marsalis (qtd. in Berliner 2)
}

Unpacking the "mystical" founding of improvisation requires, perhaps surprisingly, an initial attentiveness to Derrida's work on law and justice. Of particular relevance is the consideration given in both "Before the Law" and "Force of Law" to the "difficult and unstable distinction between justice and law" (Derrida "Force" 250), which can be likened to the "problematic relation between the singular and the general" (Attridge "Before the Law" 181; see also Derrida "Before the Law" 187) or the "antinomy between the general and the particular" (Belay 125). In a move that mirrors their dominant conceptualization in Western society, Derrida positions justice as singularity in opposition to a more generalized law. For Derrida, "justice" - "infinite, incalculable, rebellious to rule and foreign to symmetry, heterogeneous and heterotropic" (Derrida "Force" 250) - "always addresses itself to singularity, to the singularity of the other, despite or even because it pretends to universality" (248). Phrased slightly differently, as "[e]ach case is other, each decision is different" (251), justice "requires an absolutely unique interpretation, which no existing, coded rule can or ought to guarantee absolutely" (251). Law, in contrast, is described as "a system of regulated and coded prescriptions" (250, emphasis added). It is constituted solely in terms of its "generality" (245) and "universality" (245), as that which always follows pre-existent and "given" (253) rules. For Derrida, the issue then becomes how to reconcile the "event" or "act of justice" (245) with the rules, norms or imperatives that "necessarily have a general form, even if this generality prescribes a singular application in each case" (245).

Upon setting up the dichotomy between law and justice, Derrida proceeds to dismantle it: "Everything would still be simple if this distinction between justice and law were a true distinction" ("Force" 250). He makes evident that not only does law claim to "exercise itself in the name of justice" (251), but "justice demands for itself that it be established in the name of a law" (251). Justice, as "unlimited responsiveness to the other" (Fitzpatrick "Access" 4), exists solely as "an experience of the impossible" (Derrida "Force" 244). It can only be made "possible, in the sense of becoming existent, and given operative force" (Fitzpatrick "Access" 4) through law. The aporia of justice "demands decision" (Beardsworth 5). Each judicial act of deciding thereby "cuts into and enacts justice, even whilst denying justice as illimitably responsive" (Fitzpatrick "Access" 4; see also Fitzpatrick "Dominions" 144). Justice, in other words, is "dependent on the determinate presence effected by the legal decision" (Fitzpatrick "Access" 4). As Derrida explains: "No justice is exercised, no justice is rendered, no justice becomes effective nor does it determine itself in the form of law, without a decision that cuts and divides" (Derrida "Force" 252).

Not only is law "necessary for justice" (Fitzpatrick "Access" 4), so too is justice, as the "undecideable" (Derrida "Force" 253), "necessary for law" (Fitzpatrick "Access" 4): "The undecideable remains caught, lodged, as a ghost at least, but an essential ghost, in every decision, in every event of decision" (Derrida "Force" 253, emphasis added). Peter Fitzpatrick ${ }^{30}$ explains. Law, he writes, "cannot be [...] enduringly 
ordered and predictable" (Fitzpatrick "Access" 8). If it were, "there could be no call for decision, for determination, for law" (9). Instead, for law to endure, it requires a simultaneous "responsiveness" (9), an "attunement and attentiveness to what is beyond" (9). Law, argues Fitzpatrick, must be able to "change and adapt to such other things as 'society,' or "history"' (9; see also Fitzpatrick "In the End" 464). And this responsiveness to the other of law is "essential for law" (Fitzpatrick "Access" 9, emphasis added).

A similar irresolution exists in relation to invention. In "Psyche: Inventions of the Other", Derrida critiques the "traditional and dominant value of invention" (44), which must, "by definition" (Derrida "Psyche" 41), "break with convention" (41); it must "overflow, overlook, transgress, negate" (41) that from which it comes. So too must it "transgress" (41) or break with law. As Derrida writes: "every invention should make fun of the statutory" (45) and every invention "always presupposes some illegality, the breaking of an implicit contract" (25). However, "true" invention, or what Derrida calls the "invention of the other" (55), is impossible because there can be no invention "without a prevailing statutory context" (45). Stated differently, invention exists solely on the condition that it transgresses the "status" (41) with which it is supposed to comply. This "status," like law, is constituted as "stable, established, and legitimated by a social or symbolic order in an institutionalizable code, discourse, or text" (45).

Returning to the "problematic between the singular and the general" (Attridge "Before the Law" 181), the singular "event" of invention demands its simultaneous capture within a "system" of conventions that will ensure its position more generally in culture and society (Derrida "Psyche" 28). Thus, whilst the event of invention "can take place only once" (51), invention more generally must be "essentially repeatable, transmissible, and transposable" (51); "to take place as an event, it must already compromise its singularity with the conditions of recognisability that take the form of structures of repeatability or iterability" (Bennington "Double Tounging," emphasis in original). It is therefore a paradox or aporia that "invention is constituted by its originality [...] and yet wholly dependent on recognition and legitimation (and therefore subject to codes and laws)" (Attridge "Psyche" 310). It remains forever captured within the "order of the calculable" (Derrida "Psyche" 55), the "order of the same" (55), which is, for Derrida, the order of law (Derrida "Force" 244). To be otherwise would make its recognition as invention impossible.

Invention thus needs to be with law in order to be inventive. Its originality can only be "display[ed]" (Derrida "Psyche" 27), can only be brought into presence or made present, through law, through the "values of form and composition" (27); and law is "necessary not only for it to be recognized, identified, legitimized, institutionalized as invention (to be patented, we might say), but for invention even to occur, or, let us say, for it to come about" (44, emphasis in original).

Just as invention needs law, so too does law need invention in order to remain properly commanding in Western society. As revealed by Derrida in "Force of Law":

To be just, the decision of the judge, for example, must not only follow a rule of law or a general law [Ioi] but must also assume it, approve it, confirm its value, by a reinstituting act of interpretation, as if, at the limit, the law [loi] did not exist previously - as if the judge himself invented it in each case. Each exercise of justice as law can be just only if it is a "fresh judgment". (Derrida "Force" 251, emphasis added)

The impossible but "utter responsiveness" (Fitzpatrick "Law Like Poetry" 287) of invention consequently becomes the "undecideable" (Derrida "Force" 253), which haunts the legal decision and ensures that law never becomes completely or "perfectly stilled" (Fitzpatrick "Access" 9; Fitzpatrick "Breaking the Unity" 58). In its concern for the other, invention effectively sustains the need for decision, sustains the need for law (Fitzpatrick "Access" 9; Fitzpatrick "Breaking the Unity" 58).

The "undecideable relation between the general and the singular" (Beardsworth 25), "between universality and singularity" (25), subsequently demands that law and invention exist solely as "aporia" (Derrida "Force" 244). The aporetic nature of invention, for instance, rests on the fact that "true" invention would "appear" only "in terms of an entirely open responsiveness to the other" (Fitzpatrick "Access" 3), which would of course be impossible. To exist in such singularity (Derrida "Force" 248) would mean that it would have to stand "opposite the universal [law] in its completeness" (Fitzpatrick Modernism 63). If this were so we would "be deprived of all relation with it" (Nancy 60) and could not know it as invention. Equally, if law's content was completely non-inventive or "perfectly stilled" (Fitzpatrick "Access" 9) "it would cease to rule the situation that would inexorably change around it" (9). Law can thus not be "merely or fixedly determinant" (Fitzpatrick Modernism 6); it must instead remain "responsive to historical change, or to the needs of the nation, or to 
the development of society" (Fitzpatrick "No Higher Duty" 236). In stark contrast to its purported fixity and stability, law "will have accommodated changing facts, all coming from beyond it" (236).

In their deconstruction of "absolute singularity" (Derrida Deconstruction Engaged 90), Derrida's writings on law and invention become extremely relevant to this study of improvisation - for it is the "ideal of singularity" (Maras), which most often activates notions of improvisation in Western society. A deconstructive reading of jazz improvisation thus exposes the "social repressiveness of the traditional concept" (Attridge "Psyche" 310) and reads improvisation likewise as aporia. To help explain: the singularity of the improvised act must be an "inaugural event" (Derrida "Psyche" 28), a "first time ever" (qtd. 28). Yet, this "first time", in order to be a completely original and "unique moment" (29), must also be a "last time" (29; see also Derrida "Shibboleth" 2). It must be singular, complete and containable. To be so "totally present" (Birmingham 131), however, would make it "not the same" (Fitzpatrick Modernism 43) and "completely different to us" (43). If this were the case "there would be no possibility of adequate relation to it in order for us to know it" (43). The "singularity" of improvisation must thus be understood as "original repetition" (Birmingham 131), as "iterability" (Derrida "Psyche" 51), in which the "instituting act" (Birmingham 131) only gains meaning through "the repetition of an origin with which it cannot coincide, since it is of the very essence of the origin to be pure anteriority" (131). The "singular, creative event" (131) is accordingly "marked by the lack of selfpresence" (131) and it is this "repetition" (Derrida "Psyche" 51), as the "law of the singular event" (Derrida "Last Interview" 8), which makes the originality of improvisation possible in the first place (Birmingham 131).

Law and jazz thus coalesce in the irresolution of the improvised act. The "aporetic relation between (the failure of) generality and (the failure of) singularity" (Beardsworth 43), "between the law and the singular" (41), requires "some subsisting relation and thence some commonality" (Fitzpatrick Modernism 59) between the responsiveness that is privileged in jazz and the determinacy deemed essential to law. Law cannot subsist without jazz's responsive "opening onto all that lies beyond" (59) just as jazz requires "some" determinacy in order to endure as a "contained, distinct being" (59), to endure as jazz. It is therefore "the necessity yet impossibility" (Fitzpatrick "Cause of Law" 464) of both pure determinacy (law) and pure responsiveness (jazz), which "iteratively impel[s]" (464) both law and jazz "into existence" (464). The "originary repetition" (Beardsworth 32) of improvisation becomes its law $(32,35)$ and without such improvisation could not exist.

\section{The Necessity of Improvisation's Impossibility ${ }^{31}$}

Revisiting the Coleman-Derrida collaborative engagement, if jazz music, even that as "radically improvisational" (Soules 270) as Ornette Coleman's, can never be truly inventive or properly escape the "clammy grasp of law" (Haldar 7), what so moved Derrida to join Coleman on stage at the 1997 Paris Jazz Festival? Expressed more generally, "why, exactly, does improvisation matter" (Heble "Editorial" 1) to deconstruction and, by extension, to law and jazz? The answer to all these queries lies, I believe, in différance, ${ }^{32}$ in the "formal play of differences" (Derrida Positions 26), "of traces" (26), which "forbid at any moment, or in any sense, that a simple element be present in and of itself, referring only to itself" (26, emphasis in original). Improvisation "of some inaugurality" (Derrida Monolingualism 66) may be "the impossible itself" (66), but the différance of improvisation ensures that its impossibility is "not the opposite of the possible" (Beardsworth 26, emphasis in original). Instead, it "supports" (Derrida Paper Machine 91) and "releases the possible" (Beardsworth 26, emphasis in original).

It follows then that Derrida is "not against the impossible" (Caputo 20), not against improvisation. Quite the opposite. As he stated in one interview: "I believe in improvisation and I fight for improvisation. But always with the belief that it's impossible" (Derrida "Unpublished Interview"). Improvisation, as Derrida posits in relation to deconstruction, "loses nothing from admitting that it is impossible" (Derrida "Psyche" 36). It is instead "possibility", which hinders and constrains - for possibility contains "the danger of becoming an available set of rule-governed procedures, methods, accessible approaches" (36). It contains the danger, if you will, of becoming fully determined law. It is thus the impossibility of improvisation (Derrida Monolingualism 66), which gives it "hope and possibility" (Fischlin and Heble 11). For if improvisation were truly possible, in the sense of being wholly improvised or original, there would be no call for spontaneous invention or, by analogy, for jazz. It is therefore "the attempt at such an improvisation, necessarily failing," (Bennington "Double Tounging"), which "leaves a trace or a mark that can be seen as a promise of such an inaugurality" (Bennington "Double Tounging", emphasis in original). In its failure, improvisation survives. "Affirmez la survie". ${ }^{33}$ 
Improvisation thus matters to Derrida because "[d]econstruction is inventive or it is nothing at all" (Derrida "Psyche" 42); and it is "not just inventive, it is called by the other" (Bernasconi 118). The "inventive' side to Derrida's philosophy" (Beardsworth xiv) thereby aims to "reinvent invention" (Derrida "Psyche" 44) in order to "make a space for an inventiveness open to the wholly other" (Attridge "Psyche" 310). This openness of improvisation towards the other, "towards the unknown" (Bailey 54), not only sustains jazz as a creative art form, it also nurtures the possibility of "improvised musicking" ${ }^{34}$ (Fischlin and Heble "Other Side" 26; see also Fischlin 10) as that which links jazz to ethics (Heble Landing 200), resistance (Siddall 10; Fischlin and Heble "Other Side" 2, 4; Fischlin and Heble Rebel Musics) and democracy (Beyer 552).

Similarly, the responsively open dimension of improvisation matters to Western law for, without such, "we might not associate a legal decision with justice, even if it were fully in conformity with the law" (Deutscher 98). The openness, which accompanies any invention in law, "protects the possibility of radical transformation within an existing legal system" (Cornell 167) and enables us to "resist or rise up against an iniquitous law" (Bennington "Derridabase" 194). It ensures, in other words, that "law cannot inevitably shut out its challengers and prevent transformation" (Cornell 165, emphasis in original). As Bennington writes: "In this opening of the other (toward the other, called by the other), without which the same would not be, there is a chance of something happening" (Bennington "Derridabase" 14-15, emphasis added). This openness to the other thus becomes an "openness to transformation" (Cornell 166) within law, within society.

Such is the promise of the "law of the singular event": "endless revolution" (Derrida "Last Interview" 8) and hope of reform, "otherwise determined" (8).

\section{Acknowledgements}

This article owes much to the support, guidance and intellectual inspiration of Professor Peter Fitzpatrick. Deep appreciation must also be conveyed to Bhaljit Dhadda, Andrew Laking, George Laking, Sundhya Pahuja and my colleagues at the Birkbeck School of Law Postgraduate Student Conference 2005, all of whom were invaluable in their feedback and encouragement. Lastly, this work would not have been possible without the stimulating comments and direction offered by the anonymous reviewers and the editors of this journal.

\section{Notes}

${ }^{1}$ This title gestures towards Henry Louis Gates' concept of "Signifyin(g)" as a model of improvisation that is "'nothing more' than repetition and revision" (Gates 63-64). Placing Gates and Derrida in close proximity is purposeful and hints at potential parallels between Gates' theory and Derrida's understanding of improvisation as "iterability" (Derrida "Psyche" 51), as the "invention of a law of the singular event" (Derrida "Last Interview" 8). This "law of the singular event" arises out of Derrida's last interview (Le Monde, 19 August 2004) in which he is quoted as saying: "If I had invented a writing it would have been as an endless revolution. Each situation demands the creation of a suitable mode of exposition, the invention of a law of the singular event..." (8, emphasis added) ["Si j'avais inventé mon écriture, je l'aurais fait comme une révolution interminable. Dans chaque situation, il faut créer un mode d'exposition approprié, inventer la loi de l'événement singulier..." (21)]

${ }^{2}$ As a young man, Coleman was distressed about having to make his living playing in gaming houses and brothels (Nettelbeck 199). He told his mother that he no longer wanted to play jazz music as it was "adding to all that suffering" (Murphy 323). His mother's response - "you want somebody to pay you for your soul?" (qtd. 323) - liberated him from the "world of commerce and corruption" (Nettelbeck 199) and led him to "make music with and for his soul" (199). This anecdote, recounted by Coleman before the concert (see Murphy), inspired Derrida to recite the following onstage:

Soul and the music of the soul, what is it? What does it mean? How do we recognise it, soul? Beyond all the psycho-theologico-spiritualist discourse? By the fact that it can't be sold or turned into capital pre-emptively; it's the failure of capital, it's the ultimate revolution, it's unsellable from birth, when it happens, when it's created, and when it's not 
calculated, and when it suddenly shifts its ground in a blast of saxotelephone of which neither the eye nor the ear had warning, even though so much work, as with Coleman, had gone into writing [...]. (qtd. in Nettelbeck 200; for the full text, see Derrida "Play")

${ }^{3}$ Bruce King admits to being "a member of that audience booing Derrida to shut up" (King). He defends his actions by stating: "Derrida was not listed on the programme, he was not announced, and I paid my money to hear Coleman" (King).

${ }^{4}$ Derrida recalls: "His [Coleman's] fans were so unhappy they started booing. It was a very unhappy event. It was a very painful experience" (qtd. in Stein).

${ }^{5}$ Harmolodics: "Harmony, Motion and Melody" (Lake). According to Steve Lake, writer for Wire magazine:

[...] harmolodics in practice means this: You solo all the time and you stay out of the other guy's way. The source for this improvisation is of Ornette's notating but the charts are only there as raw source material. You don't necessarily play the note that's written on your sheet music, Dewey Redman once said, you just have to hold in your mind the way in which Ornette might play it.

Once the head of the melody is negotiated, and that too may be placed quite approximately, the musician is free to play on any of the melody's centres. A certain note sequence might set up its own momentum when explored more thoroughly. Or, more vaguely still, the player might choose to focus on what he considers the feeling of the melody. (Lake, emphasis in original)

${ }_{7}^{6}$ For a critique of this division, see Chapter 3 of Derrida's Of Grammatology.

7 The rigid dichotomy constructed as between Derrida and Coleman, while productive for this enquiry, is actually somewhat misleading. It is not Coleman, but those "on the outside" (Murphy 320), who view free jazz as music without law. In an interview with Derrida on 23 June 1997, Coleman explains:

[...] like when I was doing free jazz, most people thought that I just picked up my saxophone and played whatever was going through my head, without following any rule, but that wasn't true.

$[\ldots]$

What's really shocking in improvised music is that despite its name, most musicians use a "framework [trame]" as a basis for improvising. [...] it's totally improvised, but at the same time it follows the laws and rules of European structure. And yet, when you hear it, it has a completely improvised feel [air]. (Murphy 320-21)

${ }^{8}$ L'Amour Fou - "mad love" - is Haldar's subject. This doctrine, which found its form in the $20^{\text {th }}$ century surrealist technique of "automatic writing", "forces us to think of a moment of pure passion as a literary experience that properly escapes the clammy grasp of law" (Haldar 7). Haldar questions whether we can actually say that automatic writing "brings down the law?" (5). His answer? "Clearly not. Indeed automatic writing fully expresses Bataille's idea of an Icarus complex. That is, what looks like mad love, is nothing more than the law of law; it is nothing more than the repetition of man's vertical aspirations" (5).

9 See, for example, "Before the Law" (1992) and "Force of Law: The 'Mystical Foundation of Authority"' (2002). For the purposes of this article, all references to "Force of Law" will be from the Acts of Religion (2002) version, which revised the 1989 translation in order to "include the changes made in the latest French edition of the text, published in 1994" (Anidjar 229).

${ }^{10}$ See Derrida "Psyche".

${ }^{11}$ According to The Oxford English Reference Dictionary (OERD), to "improvise" is to "compose or perform (music, verse, etc.) extempore" (OERD 710, emphasis added).

12 Invention is defined as the "creation of something which did not exist before" (Black 824).

13 The caution is now customary when positing a methodological orientation that is deconstructive in nature. Not only was Derrida extremely suspicious of the title "deconstruction" (Critchley 27), to call it a "framework", "method", "theory" or even a "reading" shamefully belittles the complexities of deconstructive thought (Beardsworth $x v$ ). Borrowing from Jacqueline Rose: "it would be a grave error to describe [deconstruction] as system or school of thought because it has seized schools and systems by their very nerve endings, leaving nothing as it was before" (Cixous and Derrida "The Language of Others" 1). One may be obliged to 
employ such words when describing deconstruction, but the spectre of this warning necessarily haunts each use.

${ }^{14}$ The "jazz form" references an improvisation that is not "structure-less or chaotic" (Alterhaug 103), but instead requires some sort of framework or pre-determined form or structure (Murphy 321).

${ }^{15}$ Cobusen explains the importance of the "other" to deconstructive theory:

Especially in his later works, Derrida often speaks of "l'invention de l'autre," where "l'autre" ("the other") may be regarded as that which remains unthought, that which escapes the grip of our concepts. The other is whatever resists, escapes definition whenever definition is put in place. Recognition of the other opens the ethical dimension of deconstruction which consists in opening, uncloseting, destabilizing foreclusionary structures so as to allow passage toward the other. No culturally based directive, but the other appealing to me very concretely. No laws of tolerance, hospitality or acceptance but my singular relationship to a singular other. Deconstruction can be thought of as a reading and writing strategy that takes notice of traces of the other, of the unthought, the invisible, the unheard without absorbing, assimilating or reducing it to the same (to the cognitive power of the knowing subject or self-consciousness). (Cobusen "Music, Deconstruction, and Ethics" para. 3)

${ }^{16}$ Variations on this response have also been attributed to "Fats" Waller and Duke Ellington (Townsend 162).

17 Michael Jarret makes a similar argument:

The entire history of jazz can be heard as one colossal improvisation defining what improvisation can be: jazz is one answer to the question, What is improvisation? Getting this definition into words, however, or between the covers of a book requires either trickery or violence. When we write about improvisation, what are we really writing about? (Jarrett 321)

18 The "Uncle Tom" caricature, derived from the main character in Harriet Beecher Stowes' novel Uncle Tom's Cabin (1852), has become a "slur used to disparage a Black person who is humiliatingly subservient or deferential to White people" (Pilgrim).

19 The word "improvisation" is derived from the Latin improvisus, which "refers to the 'unforeseen' or that which occurs 'on the spur of the moment"' (Alterhaug 98).

${ }^{20}$ This sentiment is backed by musician Andrew Laking:

One question I thought of is: why are so many listeners being fooled? Probably because they don't understand the music well enough (and who could blame them). Perhaps also because most people seem to think that jazz musicians are naturally talented, but certainly not hard working; it's something you do for fun. This belief would make it hard for people to realise that it's less about spontaneous creation and improvisation, but more about hard work and long term commitment. (Personal Communication, 20 June 2005)

${ }^{21}$ Lewis adopts the terms "Eurological" and "Afrological" in order to "refer metaphorically to musical belief systems and behavior that [...] exemplify particular kinds of musical "logic"' (Lewis "Improvised" 133). The "Eurological" view sees improvisation as "pure spontaneity" (148) unmediated by "history or memory" (147). This is compared to the "Afrological" approach, which emphasizes "personality" (156), "discipline" (153), "technical knowledge of music theory and of one's instrument" (153) and a "thorough attention to the background, history, and culture of one's music" (153).

22 Precedent, defined as an "adjudged case or decision of a court, considered as furnishing an example or authority for an identical or similar case afterwards arising from a similar question of law" (Black 1176), is by no means the only device utilised by law in order to control invention. However, it will be the sole focus here.

${ }^{23}$ One way the "accomplished improviser" (Gabbard 315) can disguise the "jazz form" (Finkelstein 71) is by "learn[ing] the codes that connote freshness, looseness, and a feeling of spontaneity" (Gabbard 315, emphasis added). Such learned procedures can "create a pattern so complex that we get an illusion of randomness" (Nachmanovitch 27).

${ }^{24}$ Derrida restricts his discussion of invention in "Psyche" to what he views as the "only two major types of authorized examples for invention" (Derrida "Psyche" 32, emphasis in original): invention of "stories (fictional 
or fabulous)" (32, emphasis in original) and invention of "machines, technical devices or mechanisms, in the broadest sense of the word" (32, emphasis in original).

25 The best estimate I can give is sometime between 1982, the year Scritti Politti released the song "Jacques Derrida," and early 1988 when Gartside mentions in a 5 March 1988 interview in Melody Maker that he had "met Derrida" (Reynolds). No mention is made of this meeting in any interviews I have read prior to this date.

${ }^{26}$ Writes Cobussen: "In spite of the fact that Derrida's deconstruction of a text by Rousseau (in Of Grammatology) deals with the hierarchical relation between melody and harmony, this can by no means be called a musical deconstruction or a deconstruction in music" (Cobussen "Justification" para. 5).

${ }^{27}$ For a view, which opposes Cobussen, see Jacques Attali's Noise:

To my mind, the origin of music should not be sought in linguistic communication. Of course, the drum and song have long been carriers of linguistic meaning. But there is no convincing theory of music as language. The attempts that have been made in that direction are no more than camouflages for the lamest kind of naturalism or the most mundane kind of pedantry. The musical message has no meaning, even if one artificially assigns a (necessarily rudimentary) signification to certain sounds, a move that is almost always associated with a hierarchical discourse. (Attali 25)

${ }^{28}$ For two engaging and insightful critiques of the opposition of law to music more generally, see Desmond Manderson's Songs Without Music: Aesthetic Dimensions of Law and Justice (2000) and Peter Goodrich's "Operatic Hermeneutics: Harmony, Euphantasy, and Law in Rossini's Semiramis" (1999).

${ }^{29}$ Here I am borrowing from the title of Derrida's pioneering article, "Force of Law: The 'Mystical Foundation of Authority'," which will be discussed in detail in this section.

30 Fitzpatrick adeptly captures the aporetic nature of Western law through his unpacking of the relation between the "responsive" and "determinate" dimensions of law in modernity. For quite a comprehensive and accessible summary of Fitzpatrick's philosophy, see his interview with Jill Stauffer in The Believer (Fitzpatrick "In God We Trust").

${ }^{31}$ This is taken from Derrida's essay "As If It Were Possible, 'Within Such Limits"' in which he discusses the "Necessity of Impossibility" (Paper Machine 87).

32 Derrida takes a certain "revenge" (Bennington "Derridabase" 71) on speech through his "invention" (71) of the "witticism" $(70,71)$ différance, which inserts an "a" in place of the "e" in order to capture the "dual movement" (Smith 44) of difference and deferral (Attridge and Baldwin). Vengeance is unleashed in the fact that the difference between the two words is "only marked in writing" (Bennington "Derridabase" 70-71) (both différance and différence are pronounced the same way in French), obliging speech "to take its own written trace as its reference" (71) if it wants to "say this difference" (71, emphasis added).

${ }^{33}$ This imperative, translated into English as "Affirm the survival", was among the "few lines" (Butler 25) left by Derrida to be read by his son Pierre at his funeral in October 2004 (25).

${ }^{34}$ The concept "musicking", coined by Christopher Small and referenced in Fischlin and Heble, recognizes that improvisation is not necessarily or essentially ethical, resistant or democratic. Not all improvised music, in other words, aligns itself "with antihegemonic resistance or critical strategies of alternative community building" (Fischlin and Heble "Other Side" 2). However, there does exist an "identifiable and radical form of improvisational practices" (2), which activates "critical modes of resistance and dialogue" (2) and orients us towards the other, towards "the other side of nowhere" (Sun Ra, qtd. 1).

\section{Works Cited}

“Head-to-head: Religious hate bill." BBC News. 31 January 2006. June 2006. <http://news.bbc.co.uk/1/hi/uk politics/4664820.stm>.

Allsop Kenneth. "Twenty-One Years of Jazz." Gentleman's Quarterly Winter 1961-1962. 28-51.

Alterhaug, Bjørn. "Improvisation on a triple theme: Creativity, Jazz Improvisation and Communication." Studia Musicologica Norvegica 30 (2004): 97-118.

Anidjar, Gil. "A Note on 'Force of Law'.” Jacques Derrida. Acts of Religion. Ed. Gil Anidjar. New York and London: Routledge, 2002. 228-229. 
Attali, Jacques. Noise: The Political Economy of Music. Trans. Brian Massumi. Minneapolis and London: $U$ of Minnesota P, 1985.

Attridge, Derek. "Editor's Introduction to 'Before the Law'." Jacques Derrida. Acts of Literature. Ed. Derek Attridge. New York and London: Routledge, 1992. 181-182.

---. Editor's Introduction to 'Psyche: Invention of the Other'." Jacques Derrida. Acts of Literature. Ed. Derek Attridge. New York and London: Routledge, 1992. 310-311.

Attridge, Derek and Thomas Baldwin. "Obituary: Jacques Derrida." The Guardian. 11 October 2004. June 2006. <http://www.guardian.co.uk/obituaries/story/0,3604,1324160,00.html>.

Bailey, Derek. Improvisation: Its Nature and Practice in Music. Second Edition. New York: Da Capo Press, 1992.

Beardsworth, Richard. Derrida \& the Political. London and New York: Routledge, 1996.

Belay, Boris. "Justice: The Law of the Law." Applying: To Derrida. Eds. John Brannigan, Ruth Robbins and Julian Wolfreys. London: MacMillan, 1996. 124-135.

Belgrad, Daniel. The Culture of Spontaneity: Improvisation and the Arts in Postwar America. Chicago and London: U of Chicago P, 1989.

Bennington, Geoffrey. "Derridabase." Geoffrey Bennington and Jacques Derrida. Jacques Derrida. Trans. Geoffrey Bennington. Chicago and London: U of Chicago P, 1993. 1-316.

---. Double Tounging: Derrida's Monolingualism." June 2006. <http://www.usc.edu/dept/complit/tympanum/4/bennington.html>.

Berliner, Paul. Thinking in Jazz: The Infinite Art of Improvisation. Chicago and London: U of Chicago P, 1994.

Bernasconi, Robert. "Politics Beyond Humanism: Mandela and the Struggle Against Apartheid." Working Through Derrida. Ed. Gary B. Madison. Evanston, Illinois: Northwestern UP, 1993. 94-119.

Beyer, Jonathon A. "The Second Line: Reconstructing the Jazz Metaphor in Critical Race Theory." Georgetown Law Journal 88.3 (2000): 537-563.

Birmingham, Peg. "Toward an Ethic of Desire: Derrida, Fiction, and the Law of the Feminine." Feminist Interpretations of Jacques Derrida. Ed. Nancy J.Holland. University Park, Pennsylvania: Pennsylvania State UP, 1997. 127-146.

Black, Henry Campbell. Black's Law Dictionary. Sixth Edition. St. Paul, Minneapolis: West, 1990.

Bork, Robert H. "The Judges Role in Law and Culture." Ave Maria Law Review 1 (2003): 19-29.

Brunette, Peter and David Wills, eds.. "The Spatial Arts: An Interview with Jacques Derrida." Deconstruction and the Visual Arts: Art, Media, Architecture. Cambridge: Cambridge UP, 1994. 9-32.

Bucholtz, Barbara K. "On Canonical Transformations and the Coherence of Dichotomies: Jazz, Jurisprudence, and the University Mission." University of Richmond Law Review 37 (2003): 425469. 
Butler, Judith. "Affirm the Survival." Radical Philosophy 129 (2005): 22-25.

Caputo, John D. The Prayers and Tears of Jacques Derrida: Religion Without Religion. Bloomington and Indianapolis: Indiana UP, 1997.

Chang, Jeff. "Brushed with Hip-hop Oil: The Terrific Return of Scritti Politti." The San Francisco Bay Guardian. June 2006. <http://www.sfbg.com/noise/18/scritti.html>.

Chevigny, Paul. Gigs: Jazz and the Cabaret Laws in New York City. New York and London: Routledge, 1991.

Cixous, Hélène and Jacques Derrida. "The Language of Others." Jewish Book Week Lecture. Chair: Jacqueline Rose. 1 March 2004. London, England. June 2006.

<http://jewishbookweek.com/archive/010304e/transcripts2.php>.

Cobussen, Marcel. "Derrida's Ear." Deconstruction in Music. Interactive Online Diss. Erasmus University, Rotterdam, The Netherlands, 2001. <http://www.deconstructioninmusic.com/>.

---. Justification." Deconstruction in Music. Erasmus University, Rotterdam, The Netherlands, 2001.

---. $\quad$ "Music, Deconstruction, and Ethics." Deconstruction in Music. Erasmus University, Rotterdam, The Netherlands, 2001.

---. Scritti Politti." Deconstruction in Music. Erasmus University, Rotterdam, The Netherlands, 2001.

Cohen, Maxwell T. The Police Card Discord. London and Metuchen, N.J.: Scarecrow Press and the Institute of Jazz Studies, Rutgers University, 1993.

Collier, James Lincoln. Jazz: The American Theme Song. New York and Oxford: Oxford UP, 1993.

Cornell, Drucilla. The Philosophy of the Limit. New York and London: Routledge, 1992.

Critchley, Simon. "An Ethos of Reading." Radical Philosophy 129 (2005): 26-28.

Demsey, David. "Jazz Improvisation and Concepts of Virtuosity." The Oxford Companion to Jazz. Ed. Bill Kirchner. Oxford and New York: Oxford UP, 2000. 788-798.

Derrida, Jacques. "Before the Law." Acts of Literature. Ed. Derek Attridge. New York and London: Routledge, 1992. 183-220.

---. $\quad$ Deconstruction Engaged: The Sydney Lectures. Eds. Paul Patton and Terry Smith. Sydney: Power Publications, 2001.

---. "Force of Law: The 'Mystical Foundation of Authority'." Trans. Mary Quaintance. Acts of Religion. Ed. Gil Anidjar. New York and London: Routledge, 2002. 230-298.

---. Of Grammatology. Trans. Gayatri Chakravorty Spivak. Baltimore and London: Johns Hopkins UP, 1976.

--- The Last Interview." Trans. Robert Knafo. SV. November 2004. June 2006. <http://www.studiovisit.net/SV.Derrida.pdf $>$. 
---. Monolingualism of the Other; or, The Prosthesis of Origin. Trans. Patrick Mensah. Stanford, California: Stanford UP, 1998.

--- $\quad$ Paper Machine. Trans. Rachel Bowlby. Stanford, California: Stanford UP, 2005.

--- $\quad$ "Play - The First Name." Trans. Timothy S. Murphy. Genre: Forms of Discourse and Culture 37:2 (2004): 331-340.

--- $\quad$ Positions. Rev. Ed. Trans. Alan Bass. London and New York: Continuum, 2002.

---. $\quad$ "Psyche: Inventions of the Other." Trans. Catherine Porter. Reading de Man Reading. Eds. Lindsay Waters and Wlad Godzich. Minneapolis: U of Minnesota P, 1989. 25-65.

---. "Shibboleth: For Paul Celan." Jacques Derrida. Sovereignties in Question: The Poetics of Paul Celan. Eds. Thomas Dutoit and Outi Pasanen. New York: Fordham UP, 2005. 1-64.

---. "Unpublished Interview." June 2006. <http://www.derridathemovie.com/readings.html>.

Deutscher, Penelope. How to Read Derrida. London: Granta Books, 2005.

DeVeaux, Scott. The Birth of Bebop: A Social and Musical History. London: Picador, 1997.

Douzinas, Costas and Ronnie Warrington with Shaun McVeigh. Postmodern Jurisprudence: The Law of Text in the Texts of Law. London and New York: Routledge, 1991.

Dworkin, Ronald. Law's Empire. Oxford and Portland, Oregon: Hart, 1986.

Ellison, Ralph. Shadow and Act. London: Secker \& Warburg, 1953.

Finkelstein, Sidney. Jazz: A People's Music. New York: International, 1948.

Fischlin, Daniel. "Take One/ Rebel Musics: Human Rights, Resistant Sounds, and the Politics of Music Making." Rebel Musics: Human Rights, Resistant Sounds, and the Politics of Music Making. Eds. Daniel Fischlin and Ajay Heble. Montréal, New York and London: Black Rose Books, 2003. 10-43.

Fischlin, Daniel and Ajay Heble. "The Other Side of Nowhere: Jazz, Improvisation, and Communities in Dialogue." The Other Side of Nowhere: Jazz, Improvisation, and Communities in Dialogue. Eds. Daniel Fischlin and Ajay Heble. Middletown, Connecticut: Wesleyan UP, 2004. 1-42.

Fischlin, Daniel and Ajay Heble. Eds. Rebel Musics: Human Rights, Resistant Sounds, and the Politics of Music Making. Montréal, New York and London: Black Rose Books, 2003.

Fitzpatrick, Peter. "Access as Justice." Windsor Yearbook of Access to Justice 23:1 (2005): 3-16.

---. $\quad$ "Breaking the Unity of the World: Savage Sources and Feminine Law." The Australian Feminist Law Journal 19 (2003): 47-60.

---. "Dominions: Law, Literature, and the Right to Death." Journal of Law and Society 31:1 (2004) 142148.

--- “'In God We Trust' Can Relieve Us of Trusting Each Other.” The Believer 3:8 (2005) 63-72. 


\footnotetext{
---. In the End, or the Cause of Law." The Worlds Cause Lawyers Make: Structure and Agency in Legal Practice. Eds. Austin Sarat and Stuart Scheingold. Stanford, California: Stanford UP, 2005. 463-468.

--- Law Like Poetry - Burnt Norton." Liverpool Law Review 23 (2001): 285-288.

---. $\quad$ Modernism and the Grounds of Law. Cambridge: Cambridge UP, 2001.

---. $\quad$ The Mythology of Modern Law. London and New York: Routledge, 1992.

--- “No Higher Duty': Mabo and the Failure of Legal Foundation." Law and Critique 13 (2002): 233252.

Frank, Jerome. Courts on Trial: Myth and Reality in American Justice. Princeton, New Jersey: Princeton UP, 1949.
}

Freud, Sigmund. Totem and Taboo: Resemblances between the Psychic Lives of Savages and Neurotics. Trans. A.A. Brill. New York: Vintage, 1918.

Gabbard, Krin. "Improvisation and Imitation: Marlon Brando as Jazz Actor." The Other Side of Nowhere: Jazz, Improvisation, and Communities in Dialogue. Eds. Daniel Fischlin and Ajay Heble. Middletown, Connecticut: Wesleyan UP, 2004. 298-318.

Gates, Henry Louis, Jr. The Signifying Monkey: A Theory of African-American Literary Criticism. Oxford: Oxford UP, 1988.

Gilroy, Paul. Between Camps: Nations, Cultures and the Allure of Race. London: Penguin Books, 2000.

Goldman, Vivien. "Ornette Coleman: Biography." June 2006. <http://www.harmolodic.com/ornette/then text.html>.

Goodrich, Peter. "Operatic Hermeneutics: Harmony, Euphantasy, and Law in Rossini's Semiramis." Cardozo Law Review 20 (1999): 1649-1671.

Green, Benny. "Jazz." The Observer. 20 November 1966. 32-43.

Haldar, Piyel. "L'Amour Fou: The Subject is Forsaken in Love." Unpublished. Law, Culture and the Humanities Conference. Hartford: University of Connecticut, March 2004 [cited with permission of the author].

Hall, Timothy S. "The Score as Contract: Private Law and the Historically Informed Performance Movement." Cardozo Law Review 20 (1999) 1589-1614.

Heble, Ajay. "Editorial-Improvising Matters: Rights, Risks, and Responsibilities." Critical Studies in Improvisation 1:2 (2005): 1-3.

---. Landing on the Wrong Note: Jazz, Dissonance, and Critical Practice. London and New York: Routledge, 2000.

Hentoff, Nat. "Jazz: Music Beyond Time and Nations." The Nat Hentoff Reader. New York: Da Capo Press, 2001. 94-100.

---. Race Prejudice in Jazz: It Works Both Ways." Harper's Magazine. June 1959. 72-77. 
Hobbes, Thomas. Leviathan. Revised Student Edition. Ed. Richard Tuck. Cambridge: Cambridge UP, 1996.

Hore, Charlie. “Jazz - A People's Music?” International Socialism Journal 61 (1993). June 2006. <http://pubs.socialistreviewindex.org.uk/isj61/hore.htm>.

Hoskyns, Barney. "Where radical meets chic." New Musical Express Magazine. October 1981. June 2006. <http://aggressiveart.org/sp uk/interviews/spuk 1980 1.htm>.

Hughes, Langston. The Best of Simple. New York: Hill and Wang, 1961.

Hyman, Peter. The Reluctant Metrosexual: Dispatches from an Almost Hip Life. New York and Toronto: Villard, 2004.

Jarrett, Michael. "Cutting Sides: Jazz Record Producers and Improvisation." The Other Side of Nowhere: Jazz, Improvisation, and Communities in Dialogue. Eds. Daniel Fischlin and Ajay Heble. Middletown, Connecticut: Wesleyan UP, 2004. 319-349.

Jones, Jonathan. "Wild Ones." The Guardian Weekend. 11 December 2004. 61-65.

Jost, Ekkehard. Free Jazz (The Roots of Jazz). New York: Da Capo Press, 1994.

King, Bruce. "Review of Colin Nettelbeck, Dancing with DeBeauvoir (2004)." API Review of Books 43 (2006). June 2006. <http://www.api-network.com/cqi-bin/reviews/irbview.cgi?n=0522851134>.

Lake, Steve. "Prime Time and Motion: Ornette Coleman." Wire Magazine 19 (1985). June 2006. <http://www.thewire.co.uk/archive/interviews/ornette coleman.html>.

Levinson, Sanford and J.M. Balkin. "Law, Music, and Other Performing Arts." University of Pennsylvania Law Review 139 (1991): 1597-1658.

Lewis, George. "Improvised Music after 1950: Afrological and Eurological Perspectives." The Other Side of Nowhere: Jazz, Improvisation, and Communities in Dialogue. Eds. Daniel Fischlin and Ajay Heble. Middletown, Connecticut: Wesleyan UP, 2004. 131-162.

---. Afterword to 'Improvised Music after 1950': The Changing Same." The Other Side of Nowhere: Jazz, Improvisation, and Communities in Dialogue. Eds. Daniel Fischlin and Ajay Heble. Middletown, Connecticut: Wesleyan UP, 2004. 163-172.

MacCormick, Neil, Rhetoric and the Rule of Law: A Theory of Legal Reasoning. Oxford: Oxford UP, 2005.

Manderson, Desmond. "From Hunger to Love: Myths of the Source, Interpretation, and Constitution of Law in Children's Literature." Law \& Literature 15 (2003): 87-135.

---. $\quad$ Songs Without Music: Aesthetic Dimensions of Law and Justice. Berkeley, Los Angeles and London: U of California P, 2000.

Maras, Steven. "Audio-visualising Derrida." Australian Humanities Review. July 1999. June 2006. <http://www.lib.latrobe.edu.au/AHR/archive/Issue-July-1999/maras.html>.

Margulies, Peter. "Doubting Doubleness, and All That Jazz: Establishment Critiques of Outsider Innovations in Music and Legal Thought." University of Miami Law Review 51 (1997): 1155-1194. 
Monson, Ingrid. Saying Something: Jazz Improvisation and Interaction. Chicago and London: U of Chicago $\mathrm{P}, 1996$.

Morgan, Pauline. "Something about Women and Monsters and a Bit of a Dance." June 2006. <http://www.dur.ac.uk/postgraduate.english/morgan.htm>.

Morrison, Toni. Jazz. New York: PLUME, 1992.

Murphy, Timothy S. "The Other's Language: Jacques Derrida Interviews Ornette Coleman, 23 June 1997." Trans. Timothy S. Murphy. Genre: Forms of Discourse and Culture 37:2 (2004) 319-328.

Nachmanovitch, Stephen. Free Play: Improvisation in Life and Art. New York: Jeremy P. Tarcher/Putnam, 1990.

Nancy, Jean-Luc. Being Singular Plural. Trans. Robert D. Richardson and Anne E. O’Byrne. Stanford, California: Stanford UP, 2000.

Nettelbeck, Colin. Dancing With DeBeauvoir: Jazz and the French. Victoria: Melbourne UP, 2004.

Nitta, Sheree L.K. "The Price of Precedent: Anastasoff v. United States." University of Hawaii Law Review 23 (2001): 795-824.

O'Reilly, John. "My Dinner with Derrida." The Independent. July 1999. June 2006. <http://www.aggressiveart.org/sp uk/interviews/spuk 1999 6.htm>.

Panish, Jon. The Color of Jazz: Race and Representation in Postwar American Culture. Jackson: UP of Mississippi, 1997.

Pilgrim, David. "The Tom Caricature." Michigan: Ferris State University Jim Crow Museum of Racist Memorabilia, 2000. June 2006. <http://www.ferris.edu/news/jimcrow/tom/>.

Pue, W. Wesley. "Policing, the Rule of Law, and Accountability in Canada: Lessons from the APEC Summit." Pepper in Our Eyes: The APEC Affair. Ed. Pue. Vancouver and Toronto, UBC Press: 2000. 3-26.

Rehnquist, James C. "The Power That Shall Be Vested in a Precedent: Stare Decisis, the Constitution and the Supreme Court." Boston University Law Review 66 (1986): 345-377.

Reynolds, Simon. "Enigma Variation." Melody Maker. 5 March 1988. June 2006. <http://www.aggressiveart.org/aof files/interviews/aof interview p3b-3.htm >.

Roberts, Chris. "Scritti Politti: Intellectual Hooliganism." Melody Maker. 2 March 1991. June 2006. <http://www.aggressiveart.org/aof files/interviews/aof interview p4-1.htm>.

Ross, Russell. Bird Lives!: The High Life and Hard Times of Charlie "Yardbird" Parker. London and New York: Quartet, 1972.

Rousseau, Jean-Jacques. The Social Contract and Discourses. Trans. G.D.H. Cole. London: J.M. Dent, 1993.

Silbey, Susan S. and Patricia Ewick. "The Double Life of Reason and Law." University of Miami Law Review 57:3 (2003): 497-512. 
Siddall, Gillian. "'I Wanted to Live in that Music:' Blues, Bessie Smith and Improvised Identities in Ann-Marie MacDonald's Fall on Your Knees." Critical Studies in Improvisation 1:2 (2005): 10-19.

Smith, James K.A. Jacques Derrida: Live Theory. New York and London: Continuum, 2005.

Soules, Marshall. "Improvising Character: Jazz, the Actor, and Protocols of Improvisation." The Other Side of Nowhere: Jazz, Improvisation, and Communities in Dialogue. Eds. Daniel Fischlin and Ajay Heble. Middletown, Connecticut: Wesleyan UP, 2004. 268-297.

Stein, Joel. "Life with the Father of Deconstruction." Time Magazine. 18 November 2002. June 2006. <http://www.time.com/time/columnist/stein/article/0,9565,391685,00.html>.

Stewart, Jesse. "Freedom Music: Jazz and Human Rights." Rebel Musics: Human Rights, Resistant Sounds, and the Politics of Music Making. Eds. Daniel Fischlin and Ajay Heble. Montréal, New York and London: Black Rose Books, 2003. 88-107.

Subotnik, Rose Rosengard. Deconstructive Variations: Music and Reason in Western Society. Minneapolis and London: $U$ of Minnesota P, 1996.

The Oxford English Reference Dictionary. Second Edition. Eds. Judy Pearsall and Bill Trumble. Oxford: Oxford UP, 1996.

Toop, David. “The Green Manifesto.” The Face. 1988. June 2006.

$<$ http://www.aggressiveart.org/aof files/interviews/aof interview p3b-2.htm>.

Townsend, Peter. Jazz in American Culture. Edinburgh: Edinburgh UP, 2000.

Williams, Martin. Liner Notes. Ornette Coleman. Free Jazz: A Collective Improvisation by the Ornette Coleman Double Quartet. New York: Atlantic Recording Corporation, 1998. 